\title{
Missionale kerk, missio Dei en kerkverband: 'n Diskussie
}

Author:
Griffel van Wyk ${ }^{1}$
Affiliation:
${ }^{1}$ Faculty of Theology,
North-West University,
Potchefstroom Campus,
South Africa
Correspondence to:
Griffel van Wyk
Email:
griffelvw@gmail.com
Postal address:
PO Box 11168, Hatfield 0028,
South Africa
Dates:
Received: 25 Oct. 2013
Accepted: 03 Mar. 2014
Published: 21 Nov. 2014
How to cite this article:
Van Wyk, G., 2014,
'Missionale kerk, missio Dei
en kerkverband: 'n Diskussie',
In die Skriflig 48(1), Art.
\#1775, 9 pages. http://dx.doi.
org/10.4102/ids.v48i1.1775
License.

License.
Missionale kerk, missio Dei en kerkverband: 'n Diskussie. Die ontluikende kerk en die missionale kerk is onderwerpe wat toenemende bespreek en nagevors word. Deelnemers aan hierdie gesprek verken steeds die omvang en onderskeie elemente van die onderwerpe met soms uiteenlopende standpunte. Noodsaaklike elemente van hierdie gesprek is deur die literêre verkenning van sekere onderwerpe nagevors gepaardgaande met afleidings, evaluering en kritiese opmerkings om groter duidelikheid oor die onderwerp te bied en sodoende 'n vrugbare gesprek te bevorder. Hierdie navorsing het ook op onlangse kritiek teen die missionale kerkbeweging in Suid-Afrika gefokus, die onderliggende rol van die missio Dei in die missionale kerkbeweging verken en die implikasies van die missio Dei vir die kerkverband aangeroer. Die blyk dat die missio Dei groot waarde inhou vir 'n vrugbare gesprek oor die ontluikende kerk asook die missionale kerk omdat dit as geskikte paradigma vir teologiese ondersoek hieroor funksioneer. Dit wil ook voorkom of dit kwessies kan hanteer wat in verskillende denominasies en die kerkverband ontstaan vanweë die ontluikende kerkfenomeen.

Missional church, missio Dei and inter-church relations: A discussion. The emerging church and the missional church are topics increasingly discussed and researched. Participants in this discussion are still surveying the extent and various elements of the subject with sometimes divergent views. Critical elements in the conversation were researched through literary exploration of certain topics accompanied by inferences, evaluation and critical discussion to provide greater clarity on the subject and promote fruitful discussions. This research further focused on recent criticism of the missional church movement in South Africa, probed the underlying role of the missio Dei in the missional church movement and touched on the implications of the missio Dei for inter-church relations. The missio Dei proves to be of much value for fruitful discussion on the emerging and missional church, because it functions as a suitable paradigm of reference and theological enquiry and also seems able to address issues arising within denominations and inter-church relations caused by the emerging church phenomenon.

\section{Inleiding}

Die identiteit en doel van die kerk is die afgelope dekade opnuut 'n vraagstuk waarvoor uiteenlopende en soms verwarrende antwoorde gebied word (Niemandt 2007:9; Sheridan \& Hendriks 2013:321; Tickle 2008:14).

Uitdrukkings wat dikwels in hierdie gesprek gebruik word, is onder andere missionale kerk, emerging church en emergent church (Roxburgh \& Boren 2009:7). Volgens Janse van Rensburg (2011:8) poog hierdie uitdrukkings om nuwe konsepte en verskynsels raak te vat ter wille van definiëring en bespreking, maar soos dit in hierdie artikel sal duidelik word, is hierdie terme ook juis die teelaarde vir misverstand en lei moontlik ten einde tot ' $n$ vrugtelose debat.

Die fokus van hierdie artikel is om konstruktief tot die gesprek oor die identiteit en die doel van die kerk by te dra. Dit word gedoen deur die landskap van hierdie konsepte in die gesprek te verken en veral deur twee sleutelonderwerpe vir 'n vrugbare gesprekvoering oor die kerk se identiteit en doel op die voorgrond te plaas, naamlik die missio Dei en die kerkverband.

\section{Literatuuroorsig}

Die rede waarom kerke opnuut oor hulle identiteit en doel besin, is volgens Niemandt (2007:10) as gevolg van drie groot verskuiwings wat 'n geweldige invloed op die kultuur en psige van mense uitoefen, naamlik Postmodernisme, die Post-Christenheid en globalisering. Post-sekularisme sou ook hierby gevoeg kon word. 
Gibbs en Bolger (2006:17-19) stel drie moontlike reaksies van kerke op hierdie tipe verskuiwings: kerke kan in ontkenning hiervan lewe; hulle kan hulself aktief hierteen probeer verskans; of hulle kan dit met 'n missionêre gesindheid tegemoet gaan.

Wanneer 'n kerk besluit het om hierdie skuiwe met 'n missionêre gesindheid tegemoet te gaan, ontstaan daar noodwendig 'n nuwe besinning oor die wese (wat die kerk is), die aard (hoe die kerk is) en die doel (waarheen die kerk op pad is) van die kerk se bestaan. Die gevolg hiervan is 'n vars begrip van die sin van die kerk se bestaan en gevolglik ook nuwe of aangepaste bedieningspraktyke in die gegewe konteks. Sodanige kerke kan volgens Niemandt (2007:46) ook ontluikende kerke genoem word. Hierdie kerke ontluik, of verrys uit die bestaande konteks en kerklandskap - 'n konsep waarna daar in die Engelse literatuur as emerging churches verwys word.

Die konsep emerging church moet geensins met' $n$ kerkverband in die tradisionele sin van die woord verwar word nie. Dit is bloot 'n breë benoeming waarmee na 'n verskynsel verwys word soos wat daar na die Reformasie van die veertiende eeu verwys word sonder ' $n$ aanduiding dat dit 'n kerkverband is of wil wees (Gibbs \& Bolger 2006:28, 29).

Gibbs en Bolger (2006:28) definieer hierdie breë beweging soos volg: 'Emerging churches are missional communities arising from within postmodern culture and consisting of followers of Jesus who are seeking to be faithful in their place and time.'

Die ontluikende kerke is baie moeilik om te groepeer en enige simplistiese benadering in die bespreking daarvan sal vrugteloos bly. Heelwat ontluikende kerke wat tipies dieselfde karaktertrekke het as kerke wat tot 'n nuwe selfbegrip kom, wil nie noodwendig in 'n formele verband met ander kerke geassosieer word nie, byvoorbeeld die Mars Hill-kerk in Seattle (Driscoll 2007).

Mark Driscoll (2008), voorganger in die Mars Hill-kerk, identifiseer wel vier stromings waarin ontluikende kerke gesorteer of gegroepeer kan word (Boks 1):

- Evangelies-ontluikend - Dit is evangeliese kerke wat slegs hulle erediens- en leierskapstyle aanpas om meer byderwets te wees, sonder om werklik in hulle plaaslike, sekulêre kultuur deel te neem en mense daar met liefde te bedien.

- Huiskerk-ontluikend - Hierdie evangeliese gelowiges glo dat tradisionele vorms van die kerk uitgedien is en dat kleiner, informele en organiese geloofsgemeenskappies in huise die antwoord vir die postmoderne wêreld is.

- Gereformeerd-ontluikend - Hieronder val kerke wat in die postmodernistiese era die semper reformandaslagspreuk van die Reformasie aangryp en die kultuur van die dag missionêr tegemoet gaan, maar teologies steeds sterk in die tradisie van die Reformasie staan.

- Liberaal-ontluikend - Sodanige geloofsgemeenskappe poog nie om die tydlose evangeliese waarhede effektief in die lig van die drie groot verskuiwings te kommunikeer nie, maar poog eerder om 'n heel nuwe inhoud aan Christenskap te gee.

Die konsepte tot dusver genoem, kan soos volg georden word. Ontluikende kerke:

- Evangelies-ontluikend.

- Huiskerk-ontluikend.

- Gereformeerd-ontluikend.

- Liberaal-ontluikend.

Dit gebeur tog toenemend dat ontluikende kerke wat soortgelyke denke oor hulle identiteit het, spontaan begin om losweg met mekaar te assosieer. ' $n$ Voorbeeld hiervan is die Emergent-groep, soos hulle formeel bekend staan. Hulle bestaan uit sekere geloofsgemeenskappe wat as deel van die liberaal-ontluikende kerke beskou kan word. Hulle werk saam aan boekreekse en konferensies (Driscoll 2008). Hulle kan soos volg in geplaas word. Ontluikende kerke (sien Boks 2):

- Evangelies-ontluikend

- Huiskerk-ontluikend

- Gereformeerd-ontluikend

- Liberaal-ontluikend

- Emergent-groep

Die basiese onderskeiding in verskillende stromings binne die breë beweging van die emerging church is van kardinale belang, veral wanneer daar gepoog word om dit te beskryf of te beoordeel. In sy kritiese boek teen die ontluikende kerk in die geheel, Jesus is die Een: Verloor ons nie die evangelie in die Emerging church nie?, erken Janse van Rensburg (2011:8) dat daar 'n onderskeid is tussen die begrippe emerging (wat die geheel behels) en emergent (wat slegs 'n kleiner onderdeel behels). Volgens hom verwys emerging tereg na die beweging in die breedste moontlike verband, terwyl ermergent na 'n bepaalde organisasie binne hierdie beweging verwys. Janse van Rensburg onderskei egter nie hoe die twee entiteite van mekaar verskil nie en poog geensins om die subtiele stromings van

BOKS 1: Stromings van ontluikende kerke volgens Driscoll (2008).

\begin{tabular}{|l|l|l|l|}
\hline \multicolumn{4}{|c|}{ Ontluikende kerke } \\
\hline Evangelies-ontluikend & Huiskerk-ontluikend & Gereformeerd-ontluikend & Liberaal-ontluikend \\
\hline
\end{tabular}

BOKS 2: Die plek van die Emergent-groep.

\begin{tabular}{|l|l|l|l|l|}
\hline \multicolumn{3}{|c|}{ Ontluikende kerke } \\
\hline Evangelies-ontluikend & Huiskerk-ontluikend & Gereformeerd-ontluikend & \multicolumn{2}{|l|}{ Liberaal-ontluikend } \\
\cline { 4 - 6 } & & & Emergent-groep \\
\hline
\end{tabular}


die emerging-beweging uit te stippel soos Driscoll (2008) dit doen nie. Die Emergent-organisasie is nie bloot net 'n bepaalde organisasie wat die algemene standpunte van die emerging-beweging verteenwoordig en poog om dit op 'n georganiseerde wyse te propageer nie. Hulle het wesenlik heel verskillende teologiese standpunte as byvoorbeeld die Gereformeerd-ontluikende groep ten opsigte van aspekte soos die gesag van die Skrif, soteriologie, die universele genade, asook die bestaan van die duiwel en die hel. Driscoll sorteer hulle daarom onder Liberaal-ontluikend in sy artikel, 'Navigating the Emerging church highway' (Driscoll 2008). Janse van Rensburg toon nie hierdie noodsaaklike onderskeid aan nie en stel dit pertinent dat hy in sy boek die begrippe emerging en emergent bloot as wisselterme gebruik. Hy analiseer en beoordeel lede van die emergent-beweging ook merendeels negatief net soos Brian McLarren in sy bespreking. Daardeur word elke moontlike dimensie van die breër emerging-beweging uiteindelik verwerp. Erkende gespreksleiers en skrywers oor die ontluikende beweging in die Suid-Afrikaanse konteks soos Stephan Joubert en Nelus Niemandt, word ook oor dieselfde kam as die Amerikaanse skrywers geskeer. Volgens Janse van Rensburg (2011:9-10) is die Amerikaanse skrywers teologies liberaal en die SuidAfrikaanse skrywers en hulle denke word afgeskiet sonder dat hulle in eie reg indringend beoordeel word. Indien daar nie ' $n$ onderskeid tussen die stromings in hierdie beweging gemaak word nie, sal die waardevolle bydrae van sekere dele van die emerging-beweging verlore wees. Geen sinvolle ondersoek, beoordeling of vordering sal ten opsigte van die onderwerp gemaak kan word nie.

Hierdie troebelheid ten opsigte van die terminologie en die afwesigheid van vordering en 'n vrugbare kritiese gesprek is ook in die resensie oor Janse van Rensburg se boek deur De Klerk (2013) sigbaar. De Klerk slaag nie daarin slaag om die groot misstap in Janse van Rensburg se boek uit te wys nie. Janse van Rensburg se prominente boek in die SuidAfrikaanse konteks wat die ontluikende kerkbeweging in totaliteit verwerp, is daarom steeds 'n groot blokkasie vir vrugbare plaaslike gesprekvoering.

\section{Metodologie}

Om groter duidelikheid op die konsepte en terminologie binne die gesprek te bied, is dit nodig om eerstens die konteks waarbinne daardie konsepte en uitdrukkings ontwikkel het, te omlyn. Hierdie konteksverkenning gee daartoe aanleiding dat die rol en implikasie van die missio Dei in die gesprek verken moet word en daarna word die implikasie van die missio Dei vir die kerkverband ondersoek. Die metodologie bestaan uit 'n literêre verkenning van die onderwerpe met deurlopende afleidings, evaluasie en kritiese bespreking.

\section{Konteks van die gesprek}

Die hernude soeke na die identiteit en die doel van die kerk geskied grootliks binne die postmodernistiese perspektief wat groot klem daarop lê dat 'n definiëring van 'n kerk onmoontlik is indien die definisie los is van die konteks waarin die kerk gewortel is (Anderson 2006:104-105). Die beredenering van hierdie perspektief is dat die plaaslike kerk as die geloofsgemeenskap altyd binne 'n bepaalde tyd en plek bestaan. Die rol van hierdie konteks moet dus verreken word wanneer daar oor die identiteit en die doel van die kerk besin word (Van Wyk 2005:1, 5).

Hoewel hierdie besinning baie prominent in die VSA is soos duidelik uit die literatuuroorsig blyk, is duidelike en beduidende spore daarvan ook op Europese bodem sigbaar dit kan veral aangedui word as 'n post-Christendom-konteks.

Die titel van die Nederlandse boek van Gerrit Noort en andere, Als een kerk opnieuw begint: Handboek voor missionaire gemeenschapsvorming (2008), is veelseggend, net soos die titel van Haak se boek, Kerk in de 21e eeuw: Weer kerk voor de wêreld zijn (2001).

Wat die Britse konteks betref, het Dave Tomlinson die gesprek in 1995 ingelei met sy boek, The Post-Evangelical (Gibbs \& Bolger 2006:34, 35). Tim Chester en Steve Timmis (2008) lewer 'n meer onlangse bydrae tot die gesprek met hulle boek, Total church: A radical reshaping around gospel and community. Die dominantste beweging in die Britse konteks wat al reeds 'n baie groot en praktiese impak op die kerklike landskap gemaak het, is die organisasie Fresh Expressions. Hierdie organisasie werk met 'n verskeidenheid denominasies en kerklike tradisies en beskryf hulle doel as die aanmoediging van nuwe vorms van kerkwees vir 'n vinnig-veranderende wêreld. Hulle aktiwiteite het tot gevolg dat honderde nuwe kerke buite en langs bestaande tradisionele kerke ontstaan. Fresh Expressions is in 2005 deur die aartsbiskoppe van Kantelberg en York, in samewerking met die Metodisteraad, van stapel gestuur. Intussen is die United Reformed Church, Church of England en vele ander deelnemers ook betrek (Fresh Expressions 2010).

'n Besinning oor die invloed van die plaaslike kerk se konteks en roepingsvervulling geniet ook in Rooms-Katolieke kringe aandag (Van Koningsveld 2005:33).

In die Suid-Afrikaanse konteks word daar ook vrae oor die kerk se rol in 'n snel veranderende samelewing en veelbesproke postmodernistiese konteks gestel (Joubert 2012; Niemandt 2007:9-15; Van Helden 2013:1; Vorster 1996:23). Niemandt se boek (2007), Nuwe drome vir nuwe werklikhede, is die eerste Afrikaanse boek wat die gesprek oor ontluikende kerke onder die aandag van die breë Afrikaanse kerkgemeenskap gevestig het. Coenie Burger (1999:98) het egter al in 1999 die problematiek van die kerk se konteks en die invloed daarvan op roepingsvervulling aangeraak met sy boek, Gemeentes in die kragveld van die Gees. Vorster (1996:23) het ook reeds in 1996 die aandag op die kerk se funksionaliteit al dan nie binne die postmoderne konteks gevestig.

In die afgelope aantal jare het die konteks waarin geloofsgemeenskappe hulself wêreldwyd bevind, wesenlik verander 
(Van Koningsveld 2005:33; Venter 2005:45-57); kerke krimp ook dramaties (Van Helden 2013:1). Hiermee saam dwing die dalende lidmaatgetalle van kerke volgens De Kock (2005:1) tot ' $n$ dringende besinning oor die roepingsvervulling van plaaslike kerke. Dikwels is plaaslike kerke in Suid-Afrika, as deel van die tradisionele gereformeerde kerkverbande, soekend na hulle eie unieke roeping in hulle konteks (Van Wyk 2005:63-84). Wanneer hierdie kerke in die lig van hulle unieke konteks en die omliggende kultuur 'n eiesoortige roeping identifiseer en antwoorde daarop formuleer in 'n poging tot roepingsvervulling, het dit dikwels spanning met hulle betrokke kerkverbande tot gevolg (Van Wyk 2005:2). Hierdie spanning veroorsaak soms dat die bedienings buiteom die kerkverband aangepak word in 'n poging om op daardie roepings te antwoord.

Verskille soos hierdie het dikwels polarisasie tot gevolg (Vorster 2004:34-36). Hierdie problematiek loop uit op die vraag oor die verhouding tussen die kerklike eenheid en verskeidenheid in die Suid-Afrikaanse kerkgemeenskap 'n kwessie wat deur die jare baie aandag ontvang het (Du Plooy 2005:18-20; Jackson 2005:7; Van Wyk 2005:3; Van Wyk 2007:32-34; Venter 1994:24-26).

Die beginsels van eenheid en verskeidenheid word wel algemeen in die kerke aanvaar, maar die eenheid word meerendeels verkeerdelik as eendersheid verstaan, wat volgens Smit (1985:84) en Kruger (2009:57) nie dieselfde begrippe is nie. In die proefskrif van Smit (2007:134) word daar ook teen hierdie misverstand gewaarsku, naamlik om die eenheid as eendersheid in die kerke te eien, veral ten opsigte van multikulturaliteit. Hierdie problematiek het ook al aandag geniet in die vraag oor watter rol 'n plaaslike kerk se roepingsvervulling in die wisselwerking tussen kerklike eenheid en verskeidenheid behoort te speel (Van Wyk 2007:33, 34).

Uit die polemiek in die Gereformeerde Kerke van Suid-Afrika (GKSA) word dit verder al hoe duideliker dat die plaaslike kerke mekaar al hoe moeiliker vind deur die tradisionele kanale van hulle kerkordes en kerklike vergaderings te benut. Venter (2007:26) se artikel in Die Kerkblad, 'Broers buite hoorafstand! Waarheen met die eenheid?', dui byvoorbeeld hierop.

Kerklike spanning het onder andere sigbaar geword in 2009 toe lede uit 'n streeksinode van die GKSA in Pretoria gestap het. Dit het geskied vanweë ontevredenheid met die feit dat ' $n$ bepaalde klassis sekere van sy predikante na daardie streeksinode afgevaardig het, maar vanweë liturgiese en kerkordelike gebruike in daardie plaaslike kerk mog hulle nie by die openlike verklaring opgestaan het nie (Jackson 2009). Beskuldigings van oneerlikheid is in hierdie verband teenoor daardie betrokke plaaslike kerke gemaak (Visser 2009:30). Hierdie oënskynlike verlies van lojaliteit aan die denominasie word soos Van Gelder dit uitwys (2008:40), dikwels slegs deur 'n toename in die regulerende karakter van die denominasie beantwoord. Op hierdie wyse word na reëls, besluite en prosedures gedraai om samewerking af te dwing eerder as om die kernoorsaak deeglik te ondersoek.

Bogenoemde kontekssnit help om die tipiese landskap en faktore te skets waarop die ontluikende kerke reageer en dit bied ' $n$ groter insig in die dinamika van die ontluiking. Die ontluiking is ' $n$ poging om in die harwar van 'n nuwe wêreld en die uitdagende plaaslike kontekste 'n roeping of missie te probeer identifiseer. Daar is egter uiteenlopende idees oor wat hierdie missie is en hoe om dit uit te leef vandaar die verskillende stromings en die verwarring. Uit die bespreking tot dusver is dit duidelik dat indien die verskillende stromings onderskei kan word, dit tot 'n meer akkurate en geldige kritiese gesprek behoort te lei met groter vrug tot gevolg.

Missio Dei is een van die konsepte wat vervolgens bespreek moet word vanweë die groot rol wat dit oor 'n breë spektrum van ontluikende kerke speel - kerke wat op soek is na 'n nuwe begip van hulle eie missie. Die missio Dei is egter ' $n$ konsep wat dikwels tot verwarring bydra aangesien verskillende groepe dit met hulle eie inhoud vul.

\section{Die onderliggende rol van die missio Dei}

Baie kerke wat in die veranderende wêreld soekend is na ' $n$ dieper begrip van hulle identiteit en doel in die dinge wat wêreldwyd aan die gebeur is, draai vir duidelikheid oor daardie missie na die missio Dei-konsep (God se sending) (Grandberg-Michaelson 2008:267; Hobbart 2008:246; Simpson 2007:76).

Die missio Dei lyk na 'n vinnige oplossing vir kerke, maar Flett (2010:5) dui aan dat die missio Dei-konsep op sigself problematies is wanneer die materiële inhoud daarvan, naamlik die leer oor die Drie-eenheid, nie ook deeglik verreken word nie. Wanneer die leer oor die Drie-eenheid nie deeglik verreken word nie, laat dit die konsep uiteindelik leeg sodat dit met 'n uiteenlopende reeks betekenisse gevul kan word (Flett 2010:5). Dit is daarom nodig om die ontwikkeling van hierdie konsep kortliks te omlyn.

Karl Hartenstein 'n Duitse teoloog, het in 1934 die eerste maal die uitdrukking missio Dei gebruik om na die feit te verwys dat God die inisiatiefnemer en onderwerp van enige sending is. Hy gebruik die term na aanleiding van Johannes 20:21: 'Soos die Vader My gestuur het, stuur Ek julle ook' (vgl. Flett 2010:131). Alhoewel Hartenstein reeds in sy 1928-voordrag, 'Was hat die Theologie Karl Barths der Mission zu sagen?', aan die onderliggende logika van die konsep geraak het (Bosch 1991:389, 390; Flett 2010:125), het hy egter nie op Barth se teologie gesteun om die betekenis en inhoud van die konsep, Trinitaries, te begrond nie (Flett 2010:124).

Die konsep sowel as die sentrale rol van die Drie-eenheid daarin is wel later populêre gebruik vanweë die Willingen International Missionary Council se konferensie in 1952. 
Die konferensietema was 'The missionary obligation of the church' (Bosch 1991:390; Flett 2010:11-17;137; Goheen 2000:49). Richebacher (2003) merk die volgende hieromtrent op:

The literature always mentions the term in the same breath as the July 1952 Willingen meeting of the International Missionary Council, as the concept came into existence at that conference. Curiously, though, the expression itself was never used during the conference. It arose in the days and weeks following the Willingen conference in the report of the Würtemburg prelate and former director of the Basel Mission, Karl Hartenstein. He created the term to summarize the main finding of the conference's closing statement, which said: 'The sending of the Son to reconcile the universe through the power of the Spirit is the foundation and purpose of mission.' The missio ecclesiae comes from the Missio Dei alone. Thus, mission is placed within the broadest imaginable framework of salvation history and God's plan for salvation. (p. 589)

Missio Dei dui hiervolgens op God se sending en aktiwiteit in die wêreld waarin kerke geroep is om deel te neem en waaruit hierdie kerke dus hulle identiteit en bestaansdoel behoort te verstaan (Goheen 2000:49-50). Die term missio Dei kan tereg as paradigma beskryf word, aangesien dit op ' $n$ hele koherente verwysingsraamwerk dui wat as vertrekpunt en fondament vir alle teologiese gesprekke kan dien.

Chung (2007:234) maak 'n insiggewende stelling oor die ontwikkeling van die missio Dei-konsep vanaf blote missiologie. Hy stel dat missiologie voor die Willingen IMC as 'n deel van die ekklesiologie beskou is, maar dat missioloë en teoloë na afloop van die konferensie sending in sy verhouding tot God drie-enig begin ontwikkel het. Volgens Chung is die hooftaak van die kerk in die missio Dei om 'n instrument in die vervulling van die missio Dei te wees. Missio Dei behels dus meer as Missiologie of die Sendingwetenskap van ouds; dit is die wese van alle teologie en alle geloofsgemeenskappe.

Flett (2010:138) beskryf verder dat die trinitariese begronding van die missio Dei-konsep, wat tydens die IMC ontwikkel is, sy oorsprong in 'n studie het wat vooraf deur die IMC aan 'n Amerikaanse werkgroep opgedra is om kerklike sending prinsipieel te begrond. Hierdie studie, 'Why missions?', begin met die afdeling, 'The Christian mission and the Triune God'. Flett (2010:138) skryf oor die inhoud van hierdie werkgroep se verslag: 'It is this study that locates the missionary act in the doctrine of the Trinity.'

Die verdere denkontwikkeling oor kerke in die paradigma van die missio Dei vind hoofsaaklik in navolging van befaamde missioloë soos David Bosch en Lesslie Newbigin plaas (Gibbs \& Bolger 2006:49).

Bosch steun op die denke en werk van Barth, Verkuyl en Hoedemaker (Bosch 1995:27-32). Barth (1956:725) beskryf God as 'n missionêre God en sien God se mense as missionêre mense. Die kerk se missionêre taak is dus nie bykomend tot die wese van die kerk nie; dit is die wese van die kerk as gestuurde geloofsgemeenskap en in haar opbou vir die uitvoering van daardie missie.
Bosch (1995) se pleidooi ná sy bespreking van die missio Dei is die volgende:

Unless the church of the west begins to understand this, and unless we develop a missionary theology, not just a theology of mission, we will not achieve more than merely patch up the church. We are in need of a missiological agenda for theology, not just a theological agenda for mission; for theology, rightly understood, has no reason to exist other than critically to accompany the Missio Dei. (p. 32)

Die implikasie van Bosch se pleidooi behels 'n ommeswaai in die benadering tot Teologie. Die verskillende teologiese vakdissiplines behoort baie meer geïntegreerd bestudeer te word met die eksplisiete fokus op die plaaslike geloofsgemeenskap se deelname aan die missio Dei. Dit is die skerp punt waarop alle teologiese nadenke moet uitloop. Alle onderskeie teologiese vakke, juis ook die PraktiesTeologiese vakke, behoort dus met 'n missionêre agenda ontwikkel te word om die geloofsgemeenskap in die praktyk by te staan. Hiersonder is daar geen sin in teologiese refleksie en toepassing nie.

Guder (2004:17) bevestig dit ook in sy intreerede as Henry Winters Luce, professor van Missionêre en Ekumeniese Teologie by Princeton Theological Seminary met sy opmerking: 'All of the classical loci of theology are, in some way, engaged by the matter of missional theology.'

Flett (2010:296), wat 'n trinitariese begronding vir die missio Dei ontwikkel het, merk op dat mission in die sin van missio Dei die sentrale saak van alle dogmatiese teologie behoort te wees. Volgens hom is die saak wat deur missio Dei tot uitdrukking kom, met slegs 'n paar uitsonderings, afwesig van die bestaande teologiese sisteem. Die afwesigheid van die missio Dei in die kontemporêre teologie het vandag 'n ingrypende negatiewe nadraai vir die kerk se opleiding, identiteit en funksionering.

Waar ontluikende kerke wel tot 'n nuwe begrip van hulle identiteit en doel kom, spesifiek in die lig van die missio Dei, vervaag die lyne tussen die tradisionele ensiklopediese indelings van die teologie deurdat hulle raakvlakke saam ontgin word en dit selfs plek-plek verdwyn (Hirsch 2006:142-147).

Allan Hirsch, tans direkteur van die internasionale organisasie Forge Mission Training Network wat missionêre leierskapsontwikkeling vir kerke doen, dring daarop aan dat die onderskeie ensiklopediese indelings se raakvlakke reg ontgin word, sodat die organiese vloei logies korrek is. In hulle poging om missionêr in 'n post-Christendomkultuur op te tree, hou hulle stewig aan die volgende formule vas: 'Christologie bepaal missiologie en missiologie bepaal ekklesiologie.' Die persoon en werk van Christus beïnvloed die doel en metodologie van alle missionêre aktiwiteit wat nie wesenlik van die aard, funksies en vorms van die kerk verskil nie (Hirsch 2006:142, 143).

Craig van Gelder, redigeerder van die boekereeks, The gospel and our culture, asook eertydse professor in Missiologie aan 
die Calvin Seminary in Grand Rapids en tans verbonde aan die Luther Seminary in Minnesota, stel ook dat teologiese ontwikkelings in die Ekklesiologie en die Missiologie al hoe beter lig werp op die feit dat sending (missiologie) en kerk (ekklesiologie) dieselfde entiteite beskryf (Van Gelder 2000:32).

Velde soos Dogmatiek, Missiologie, Ekklesiologie en Kerkreg word in werklikheid bo-oor mekaar geplaas en saam vanuit God se Drie-eenheid gelees en ontgin te word. Hierdeur word die kerk se ware identiteit op 'n holistiese wyse verstaan, eerder as om die onderskeie vakgebiede afsonderlik langs mekaar te bestudeer en te ontwikkel en nouliks oor hulle raakvlakke te besin (Hirsch 2006:142-147; Van Gelder 2000:37, 38).

Die rede hiervoor is dat die paradigma van missio Dei (tipies Dogmatiek) op die konkrete, tasbare plaaslike geloofsgemeenskap (tipies Ekklesiologie) in 'n bepaalde konteks fokus met die daaglikse deelname aan God se sending (tipies Missiologie) waardeur God se koninkryk (tipies Bassileiologie) op aarde gevestig word, ondersteun deur die verhoudings wat hierdie geloofsgemeenskappe met mekaar het (tipies Kerkreg).

Dit is juis hiérdie missio Dei-perspektief wat toenemend sekere plaaslike kerke se identiteit, wese, karakter, organisasie en uiteindelik keuses rondom die kerklike praktyk bepaal. Vandaar die nuwe beskrywing missionale kerk teenoor missionêre kerk om die verband met die missio Dei te onderskei (Gibbs \& Bolger 2006:50).

Deur kerke of groeperings van geloofsgemeenskappe met die woord missionaal te beskryf, word iets baie spesifieks bedoel. Missionaal word van die meer bekende term missionêr onderskei, om na die aard en kern van wat kerkwees in die konteks van die missio Dei beteken, te verwys. Missionaal dui 'n kerk aan waar al die elemente van die kerk op deelname aan die missio Dei gerig is. Dit word onderskei van missionêr wat na sekere aktiwiteite van die kerk verwys wat 'n missionêre doel het (Keller et al. 2011; Van Gelder 2008:vii). Kerke wat hulle identiteit en doel in terme van die missio Dei verstaan, word daarom as missionale kerke beskryf (Guder 1998:1-7; Keller et al. 2011).

Die missionale kerke is oor die spektrum van stromings binne die ontluikende beweging versprei, afhangend van hoe daardie groep die inhoud van die missio Dei definieer. Dit word in Boks 3 aangedui.

Gibbs en Bolger (2006:50) beskryf ook die missio Dei spesifiek in verhouding tot die ontluikende kerke. Hulle stel dat Adam, Abraham, Israel, Jesus Christus, Paulus, die Vroeë Kerk, die kerk deur die geskiedenis en die huidige ontluikende kerke nie aparte missies het nie, omdat daar net een missie is, naamlik God se missie. Die verskeie individue en groepe in die Skrif se ooreenstemming lê slegs in die wyse waarin hulle ten volle aan die bediening van God se versoeningswerk in die wêreld deelneem. Die ontluikende kerke wat missionaal is, beskou gelowiges as mense wat in die stroom van God se aktiwiteit vloei in samewerking met God wat vir homself 'n bruid bymekaarmaak (Gibbs \& Bolger 2006:51).

Die missio Dei kan daarom beskou word as die mees prominente vertrekpunt van die paradigma waarbinne en die motief waartoe 'n toenemende aantal ontluikende kerke as geloofsgemeenskappe funksioneer. Die bespreking oor die ontwikkeling daarvan werp ook lig op die populêre gebruik van bepaalde terminologie soos missionaal en sal hopelik bydra om vrugbare vordering in die gesprek oor ontluikende kerke te maak. Daar moet ook veral gelet word op die spesifieke trinitariese inhoud van die missio Dei deur die gebruikers van die konsep. Die detailbesonderhede hiervan val egter buite die skopus van hierdie artikel.

Een van die areas van die kerklike problematiek wat veral deur die nuwe nadenke oor die aard en doel van die kerk veroorsaak word en prakties by die besinning oor die missio Dei kan baat vind, is die kerkverband en tussenkerklike verhoudings.

\section{Kerkverband}

Die praktiese riglyne of ordereëlings wat verhoudings tussen plaaslike kerke binne 'n kerklike verband met mekaar reguleer, word tereg deur die teologiese denke en uitgangspunte van daardie kerkverband gevorm (Du Plooy 1993:8; Richey 1977:29). Alle teologiese denke is kontekstueel. Die milieu en problematiek van die dag beïnvloed die lens waardeur die Skrif benader en verstaan word (Van Gelder 2000:38). Dit is nie as sodanig verkeerd nie, omdat teologie juis die vaste, geopenbaarde waarheid van die Skrif tot die konstante veranderende praktyk van die lewe en die tydvak wil laat spreek. Probleme begin wel opduik wanneer hierdie dinamika ontken word of die teologiese denke stol.

Die milieu en problematiek van Postmodernisme, PostChristenheid en globalisering van die huidige tydvak slyp en vorm ook die hedendaagse teologiese denke en kerklike praktyk. Die dinamika van hierdie impak van teologiese denke, waar dit deur die missio Dei omraam word, behoort ook te geld ten opsigte van die praktyke en meganismes wat die verhoudings tussen plaaslike kerke reguleer wanneer hulle met mekaar assosieer.

Die teologiese denke van die Reformasie het in ' $n$ bepaalde konteks ontwikkel. Hierdie konteks was onder andere die opkomende Rasionalisme, asook die stryd teen veral

BOKS 3: Die verspreiding van die missionale kerke.

\begin{tabular}{|c|c|c|c|c|c|c|c|}
\hline \multicolumn{8}{|c|}{ Ontluikende kerke } \\
\hline \multicolumn{2}{|c|}{ Evangelies-ontluikend } & \multicolumn{2}{|c|}{ Huiskerk-ontluikend } & \multicolumn{2}{|c|}{ Gereformeerd-ontluikend } & \multicolumn{2}{|l|}{ Liberaal-ontluikend } \\
\hline Missionaal & Ander stromings & Missionaal & Ander stromings & Missionaal & Ander stromings & Emergent-groep & Missionaal \\
\hline
\end{tabular}


die Rooms-Katolieke Kerk (Tickle 2008:43-62). Binne hierdie konteks het die hedendaagse kerke van die gereformeerde tradisie hulle identiteit gevind en het hulle tiperende belydenisse, kerkordes en vergaderpraktyke ontstaan (Gibbs \& Bolger 2006:19; Tickle 2008:43-62). Hierdie neerslag van die Reformasie is noodwendig deur die konteks en problematiek van die dag geslyp en gevorm (Forney 2008:64, 65). Die logiese afleiding om te mak, is dat die teologiese onderbou en die kerklike praktyk van die huidige kerke van die gereformeerde tradisie juis deur die problematiek, vrae en konteks van 'n wêreld van 400 jaar gelede geslyp is.

Kerke wat deur die missio Dei gerig word en wat die milieu van Postmodernisme, Post-Christenheid en globalisering wil tegemoet gaan, is met 'n nuwe besinning oor die identiteit en doel van die kerk besig - 'n kerk wat alreeds besig is om op innoverende neigings en praktyke uit te loop. Soos reeds aangedui, is hierdie neigings en praktyke dikwels baie vreemd vir ander kerke van die breë gereformeerde tradisie, veral ten opsigte van die multikulturaliteit en die multi-etnisiteit in die Suid-Afrikaanse samelewing. Dit wil voorkom asof die twee paradigmas ten opsigte van die identiteit en die doel en dus ook die funksionering van die kerk toenemend in konflik met mekaar sal kom. Of die plaaslike kerk 'n missionêre taak het bo en behalwe die ander take, en of die kerk missionaal in haar wese is, het praktiese ingrypende implikasies vir sake soos die liturgie, kerklike vergaderings, teologiese opleiding in die gemeente en kerkplanting. Hierdie situasie plaas toenemende druk op die kerklike strukture en organisatoriese stelsels waar baie van hierdie aspekte moeilik ruimte of uiting kan vind.

Hierdie bron van spanning en selfs konflik laat daarom vrae oor die aard en doel van die kerkverband as sodanig ontstaan. Ten opsigte van die spanning tussen geloofsgemeenskappe stel Du Plooy (2005) die vraag in Die Kerkblad:

Ek wonder regtig of ons nog genoeg erns maak met die eenheid van die kerk, ook met ons onderlinge geloofsgemeenskap met mekaar, veral as ons van mekaar verskil. Doen ons dinge reg? (bl. 18).

Die soeke om as kerke saam 'dinge reg' te doen, word ook uit die missio Dei-perspektief verwoord. Wright (2010:23) vra in die eerste hoofstuk van 'The mission of God's people' die inleidende vrae tot sy boek 'Who are we and what are we here for?' Daar ontwikkel nuwe insigte uit die missio Dei as antwoorde op Wright se vrae, maar daarby kom egter nog 'n derde vraag oor wat gevra en geantwoord moet word, naamlik 'And how do we do it together?'

Daar is reeds aanduidings dat plaaslike kerke op 'n wyse saamwerk wat ruimte vir hulle missionale karakter laat. Insig hierin mag waardevol wees om oplossings vir die spanningsvolle konteks te bedink. Sekere ontluikende missionale kerke het deur die jare op verskillende wyses met mekaar geassosieer in missionale netwerke. Missionale netwerke is verhoudings wat tussen geloofsgemeenskappe tot stand gekom het, juis omdat hulle identiteit en doel in terme van dieselfde begrip van die missio Dei verstaan word.
Om hierdie netwerke te ondersoek, kan innoverende insigte vir die vordering van die gesprek oor missionale kerke in die Suid-Afrikaanse konteks lewer, veral ten opsigte van tussenkerklike verhoudings.

Insig moet verkry word in gevalle waar bestaande missionale netwerke reeds in ' $n$ mindere of meerdere mate met die missio Dei as paradigma funksioneer. Gevestigde missionale netwerke met deelnemende kerke wat aan hierdie beskrywing in Noord-Amerika voldoen, is onder andere die volgende:

- Redeemer City to City, gebaseer in New York, VSA (Redeemer City to City 2009-2011).

- Church Innovations, gebaseer in St. Paul, VSA (Church Innovations 2011).

- Acts 29, gebaseer in Dallas, VSA (Acts29 2011).

- Forge Canada, gebaseer in Vancouver, Kanada (Forge Canada 2009).

Al vier hierdie netwerke is in Noord-Amerika gesetel, alhoewel almal ook internasionaal funksioneer. 'n Baie kort beskrywing van die City to City-netwerk dien as voorbeeld om insig in hierdie tipe netwerke te gee.

Die City to City-netwerk bestaan uit plaaslike kerke van verskillende denominasies asook onafhanklike kerke vanoor die hele wêreld. City to City is as netwerk uit 'n spesifieke kerk, die Redeemer Presbyterian Church, gebore. Die Redeemer Presbyterian Church is ook nog deel van die Presbyterian Church of America en is dus ook deel van 'n tradisionele denominasievorm (Redeemer City to City 2012). Die deelnemende kerke aan die City to City-netwerk vind 'n eenheid in die missio Dei, maar bied mekaar ruimte vir die diversiteit van elke kerk se herkoms, kultuur, konteks, geloofsbelewing en uitlewing (Keller 2012:38).

Die ander genoemde netwerke funksioneer breedweg op dieselfde basis en kan dus almal as internasionaal en transdenominasioneel beskryf word. Elkeen is egter in sekere opsigte uniek. Acts29 is uit 'n onafhanklike kerk in die gereformeerde tradisie gebore (Acts 29 2011; MarsHill 2012). Church Innovations word deur 'n Lutherse professor in Sistematiese Teologie gelei (Church Innovations 2012), terwyl Forge Canada in die onafhanklike charismatiese tradisie gevestig is (Forge Canada 2009; Southside Community Church 2012).

Daar is dus ooreenkomste en uniekhede tussen hierdie netwerke, maar die wyse waarop hulle hulle eenheid en diversiteit in 'n transdenominasionele wyse, geskoei op die missio Dei, bestuur, maak van hulle ideale netwerke om te raadpleeg vir koersaanduidings in die konteks van die SuidAfrikaanse polemiek en problematiek ten opsigte van die ontluikende missionale kerke.

Die stand van sake in die kerkverbande van gereformeerde belydenis in Suid-Afrika dui op die groot waarskynlikheid dat plaaslike kerke wat enersdenkend ten opsigte van hulle 
identiteit en doel is, ongeag die denominasie, al hoe meer by mekaar aanklank sal vind. Hulle mag moontlik ook in sulke transdenominasionele netwerke tree en funksioneer. Dit mag egter ook met uiteenlopende motiverings van ontkenning, verskansing of missionale effektiwiteit geskied. Navorsing hieroor kan in die lig van die missio Dei uiters aktueel wees om koers aan hierdie moontlike tendens te verleen.

\section{Samevatting}

Die konteks en konsepte van die gesprek oor ontluikende kerke dui daarop dat dit noodsaaklik is om meer genuanseerd oor die verskillende stromings te praat voordat hierdie beweging sodanig bespreek kan word dat dit vrugbaar vir kerke in die Suid-Afrikaanse konteks kan wees. Om hierdie verwarring te help opklaar, kan dit nuttig wees om die onderliggende rol van die missio Dei in die ontluikende kerkgesprek te verken. Die spesifieke inhoud van wat met die missio Dei bedoel word, moet ook in berekening gebring word. Soos die missio Dei in missionale netwerke ontplooi word, het dit waarskynlik betekenisvolle implikasies vir die kerklike problematiek in tussenkerklike verhoudings. Sodanige problematiek ontstaan juis ten opsigte van die kerkverband as gevolge van die veranderende wêreld en die kerke se soeke na hulle identiteit en doel in daardie wêreld.

\section{Gevolgtrekking}

Die wêreldkonteks verander. Sommige plaaslike kerke verander in reaksie daarop, gerig deur die missio Dei, terwyl kerklike verbande en stelsels al hoe meer sukkel om die veranderings te akkommodeer. Hierbenewens is daar troebelheid ten opsigte van sleutelkonsepte wat die veranderingsbeweging probeer omvat. Hierdie troebelheid lei tot vrugtelose debatte terwyl moontlike oplossing wag om ontdek te word.

Die missio Dei, onderliggend aan 'n groot hoeveelheid missionale kerke en netwerke mag 'n vrugbare ontmoetingspunt wees vanwaar die gesprek oor die ontluikende kerke produktief kan plaasvind. Talle vrugbare resultate mag volg indien die missionale netwerke ook ondersoek word om oplossings vir die huidige kerklike problematiek daaruit te ontgin.

\section{Erkenning \\ Mededingende belange}

Die outeur verklaar dat hy geen finansiële of persoonlike verbintenis het met enige party wat hom nadelig kon beïnvloed het in die skryf van hierdie artikel nie.

\section{Literatuurverwysings}

Acts29, 2011, 'What we believe and why we believe it', viewed 22 November 2011 from http://www.acts29network.org/about/doctrine/

Anderson, R.S., 2006, An emergent theology for emerging churches, InterVarsity, Downers Grove.

Barth, K., 1956, Church dogmatics, vol. 4(1), transl. G.W. Bromiley, Clark, Edinburgh (The doctrine of reconciliation, part 1).

Bosch, D.J., 1991, Transforming mission: Paradigm shifts in Theology of Mission, Orbis, Maryknoll.
Bosch, D.J., 1995, Believing in the future: Towards a missiology of western culture, Trinity Press, Pennsylvania.

Burger, C., 1999, Gemeentes in die kragveld van die Gees, BUVTON, Stellenbosch.

Chester, T. \& Timmis, S., 2008, Total church: A radical reshaping around gospel and community, Wheaton, Crossway Books.

Chung, S.H., 2007, 'The origin of missio Dei and its implication to missional ecclesiology', viewed 01 April 2010, from http://www.earticle.net/ FileArticle/200710/633287541244687500.pdf

Church Innovations, 2011, 'Church innovations services', viewed 21 November 2011, from http://www.churchinnovations.org/01_services/services.html

Church Innovations, 2012, 'President and director of research: Patrick Keifert', viewed 12 March 2012, from http://www.churchinnovations.org/06_about/00_staff pages/stf_cns_p_keifert.html

De Klerk, B.J., 2013, 'Openhartige beoordeling van die Emerging Church', In die Skriflig/In Luce Verbi 47(1), Art. \#130.

De Kock, K., 2005, "n Prakties-teologiese beoordeling van "natural church development" se agt kwaliteitseienskappe van groeiende kerke', MTh-skripsie, Fakulteit Teologie, PU vir CHO, Potchefstroom.

Driscoll, M., 2007, 'Mark Driscoll on denominations', viewed 09 July 2010, from http://www.youtube.com/watch?v=oAnGPGd9NyM

Driscoll, M., 2008, 'Navigating the emerging church highway', Christian Research Journal 31(4), viewed 01 July 2010, from http://www.equip.org/articles/ navigating-the-emerging-church-highway

Du Plooy, A. le R., 1993, Kerkordeboekie van die Gereformeerde kerke in Suid-Afrika, Administratiewe Buro van die GKSA, Potchefstroom.

Du Plooy, A. le R., 2005, 'Kerkeenheid, kerkverband en kerkskeuring', Die Kerkblad, Maart, bl. 18-20.

Flett, J.G., 2010, The witness of God: The Trinity, missio Dei, Karl Barth, and the nature of Christian community, Eerdmans, Grand Rapids.

Forge Canada, 2009, 'Who we are', viewed 24 November 2011, from http://www. forgecanada.ca/index.php?option=com_content\&view=category\&layout=blog\& $\mathrm{d}=37$ \& Itemid $=55$

Forney, D.G., 2008, 'Living in the city-Journeying outside the gate: A missional approach to polity', in C. van Gelder (ed.), The missional church and denominations: Helping congregations develop a missional identity, pp. 64-103, Eerdmans, Grand Rapids.

Fresh Expressions, 2010, 'Changing church for a changing world', viewed 07 September 2019, from http://www.freshexpressions.org.uk/about

Gibbs, E. \& Bolger, R.K., 2006, Emerging churches: Creating Christian community in postmodern cultures, Baker Books, Grand Rapids.

Goheen, M.W., 2000, As the Father has sent Me, I am Sending you: J.E. Lesslie Newbegin's missionary ecclesiology, Boekencentrum, Zoetermeer.

Grandberg-Michaelson, W., 2008, 'Insight into becoming a missional denomination', in C. van Gelder (ed.), The missional church and denominations: Helping congregations develop a missional identity, pp. 265-282, Eerdmans, Grand Rapids.

Guder, D.L., 1998, Missional church: A vision for the sending of the church in North America, Eerdmans, Grand Rapids.

Guder, D.L., 2004, 'From mission and theology to missional theology', viewed 26 July 2010, from http://academic.sun.ac.za/buvton/Vennote/GOCN/Guder.doc

Haak, C.J., 2001, Kerk in de 21e eeuw: Weer kerk voor de wêreld zijn, Voorhoeve, Kampen.

Hirsch, A., 2006, The forgotten ways, Baker Books, Grand Rapids.

Hobbart, T., 2008, 'Missional renewal: An ecclesiology and polity proposal for the Baptist general conference', in C. van Gelder (ed.), The missional church and denominations: Helping congregations develop a missional identity, pp. 235-261, Eerdmans, Grand Rapids.

Jackson, N., 2005, 'Gesprek oor diversiteit nodig', Volksblad, 11 Februarie, bl. 7.

Jackson, N., 2009, 'Vroue in kerk: Groep stap uit streeksinode', besigtig 15 Februarie 2010, vanaf http://www.beeld.com/Content/SuidAfrika/Nuus/1928/ eb0f0c98431245fdbfb52584f02c2def/25-11-2009-02-36/Vroue_in_kerk_Groep_ stap_uit_streeksinode_ 25 November

Janse van Rensburg, J., 2011, Jesus is die een! Verloor ons nie die evangelie in die emerging church nie?, Christelike Media Publikasies, Wellington.

Joubert, S., 2012, 'Kleiner maar ruimer kerk', besigtig 09 April 2013, vanaf http:// kerkbode.co.za/kleiner-maar-ruimer-ng-kerk/

Keller, T.J., Stetzer, E., Hirsch, A., Kimbal, D., Mason, E., Greear, J.D., Ott, C., Bergguist, L., Nation, P. \& Andrews, B., 2011, 'Missional Manifesto', viewed 21 November 2011, from http://www.missionalmanifesto.net/

Keller, T.J., 2012, 'Visitors information: Redeemer Presbyterian Church', Presbyterian Church, Redeemer

Kruger, H., 2009, 'Eenheid is nie eendersheid', Die Kerkblad, 11 April.

MarsHill, 2012, 'The Mars Hill guide', viewed 12 March 2012, from http://marshill. com/pages/mission\#planting-churches

Niemandt, N., 2007, Nuwe drome vir nuwe werklikhede, Lux Verbi, Wellington.

Noort, G., Paas, S., De Roest, H. \& Stoppels, S., 2008, Als een kerk opnieuw begint: Handboek voor missionaire gemeenschapsvorming, Boekencentrum, Zoetermeer.

Redeemer City to City, 2009-2011, 'Our story', viewed 21 November 2011, from http://redeemercitytocity.com/our-story/approach.jsp

Redeemer City to City, 2012, 'History', viewed 12 March 2010, from http:// redeemercitytocity.com/our-story/history.jsp 
Richebacher, W., 2003, 'Missio Dei: The basis of mission theology or a wrong path?', International Review of Mission 92(367), 588-605. http://dx.doi. org/10.1111/j.1758-6631.2003.tb00431.x

Richey, R.E., 1977, Denominationalism, Abingdon, Nashville.

Roxburgh, A.J. \& Boren, M.S., 2009, Introducing the missional church, Baker Books, Grand Rapids.

Sheridan, T.M. \& Hendriks, H.J., 2013, 'The Emergent church movement', Nederduitse Gereformeerde Teologiese Tydskrif 53(3 \& 4), 312-323, viewed 25 October 2013, from http://hdl.handle.net/10019.1/85270

Simpson, G.M., 2007, 'A reformation is a terrible thing to waste', in C. van Gelder (ed.), The missional church in context, pp. 76-80, Eerdmans, Grand Rapids.

Smit, C.J., 1985, 'Kerkreg en kerkorde in die lig van God se reg en orde vir sy kerk', ThDproefskrif, Fakulteit Teologie, PU vir CHO, Potchefstroom.

Smit, E.J., 2007, 'Die bydrae van die gereformeerde kerklied tot die versoening en eenheid in ' $n$ multikulturele Suid-Afrika', ThD-proefskrif, Fakulteit Teologie, Noordwes-Universiteit, Potchefstroom.

Southside Community Church, 2012, 'Who is Southside?', viewed 12 March 2012 from http://www.southside.ca/index.php?option=com_content\&view=article\& $\mathrm{d}=46$ \& Itemid $=53$

Tickle, P., 2008, The great emergence, Baker Books, Grand Rapids.

Van Gelder, C., 2000, The essence of the church, Baker Books, Grand Rapids.

Van Gelder, C., 2008, The missional church and denominations: Helping congregations develop a missional identity, Eerdmans, Grand Rapids.
Van Helden, P., 2013, 'Denke as krisisterrein in die verskynsel van kerkkrimping by tradisioneel Afrikaanssprekende susterkerke', Verbum et ecclesia 34(1), 1-12. $\mathrm{http}: / / \mathrm{dx}$.doi.org/10.4102/ve.v34i1.677

Van Koningsveld, M., 2005, 'Aan de vruchten kent men de boom: Een praktischtheologische studie over activiteit en vitaliteit van de parochie', Ph D-proefskrif, Fakulteit Teologie, De Katholieke Theologische Universiteit, Utrecht.

Van Wyk, G., 2005, 'Eenheid, verskeidenheid en roepingsvervulling', MTh-skripsie, Fakulteit Teologie, Noordwes-Universiteit, Potchefstroom

Van Wyk, G., 2007, 'Eenheid, verskeidenheid, roeping', Die Kerkblad, 32-34.

Venter, H.V., 2005, 'Die begeleiding van gesinne in die plaaslike kerk binne die konteks van die Postmodernisme: 'n Prakties-teologiese benadering', MTh-skripsie, Departement Teologie, PU vir CHO, Potchefstroom.

Venter, J., 1994, 'Hoe verder met die verskeidenheid in die Gereformeerde Kerke?', Die Kerkblad, 24-26.

Venter, P., 2007, 'Broers buite hoorafstand: Waarheen met die eenheid?', Die Kerkblad 110(3204), 26-27.

Visser, J., 2009, 'Gereformeerde oneerlikheid: Diskussie', Die Kerkblad, 30-33.

Vorster, J.M., 1996, Is die kerk funksioneel?, Potchefstroomse Teologiese Publikasies, Potchefstroom.

Vorster, N., 2004, 'Hoe kan ons ons verskille oorkom?', Die Kerkblad 107(3166), 34-36.

Wright, J.H., 2010, The mission of God's people: A biblical theology of the church's mission, Zondervan, Grand Rapids. 